Przy końcu autorzy słusznie wspominają, że coraz to nowe zagadnienia i niejasności się wyłaniają, bo żaden prawodawca nie jest w stanie przewidzieć wszystkich możliwości, jakie życie nasuwa, i dlatego należy się spodziewać autentycznych wyjaśnień ze strony Kongregacıı S. Officii.

\title{
85-LECIE IKS. WILHELMA SCHMIDTA S. V. D.
}

W encyklice „Divino afflante Spiritu“ Pius XII po raz pierwszy wyraźnie zalicza etnologie do nauk pomocniczych cgzegezy biblijnej. Dlatego jest rzecza wskazaną, by czasopismo biblijne czytelników swoich zapoznało bliżej z osoba i działalnością bardzo wybitnego etnologa, lingwisty i religiologa, z Ks. Wilhelmem Schmidt'em, który w każdej z tych wymienionych nauk dokonał badań przełomowych.

Ks. Wilhelm Schmidt urodził się 16. lutego $1868 \mathrm{r}$. W Foerden w Westfalii. W 1883 r. wstąpił do Towarzystwa Slowa Bożego (skr. S. V. D. = Societas Verbi Divini $=$ Werbiści). Po święceniach kapłańskich w 1892 r. został wysiany do Berlina, gdzie studiowal przede wszystkim języki semickie: hebrajski, arabski, syryjski, aby później zająć się źródłami arabskimi i hebrajskimi średniowiecznej filozofii scholastycznej. W 1895 r. został lektorem języka hebrajskego w Seminarium zakonnym S. V. D. w St. Gabriel pod Wiedniem.

W tym ezasie (1896) Stolica Apostolska powierzyła Zgromadzeniu Slowa Bożego misje na Nowej Gwinei, gdzie na stosunkowo niewielkim obszarze spotyka się niezwykłą ilość i różnorodność języków papuaskich. Ona to zainteresowala Ks. Schmidta, kiedy opracowywal referat na temat Niisji Nowej Gwinei. Porównywania nazw liczebników w różnych językach papuaskich skierowały jego zainteresowania na lingwistykę ogólną. Przedmiotem specjalnym jego badań staly się języki Oceanii, które złączył w wielką grupę lingwistyczną, obejmującą prawie wszystkie wyspy położone między Madagaskarem i Ameryką Poludniową. Grupe tę z wdzięczności dla Austrii, której cbywatelstwo otrzymał, nazwał austronezyjska. Grupa ta jest spokrewniona z inną grupą językowa, rozpowszechniona na kontynencie azjatyckim, która się również stała przedmiotem jego badań, opublikowanych w pracy „,Das Verhältnis der melanesischen Sprachen zu den polynesischen und untereinander" (Wiedeń 1899). Dalsze badania nad językami australijskimi doprowadzily go do ich klasyíikacji i do bardzo ważnych wynilzów, ḱtóre publikuje w cbszernym dziele ,Die Gliederung der australischen Sprachen“ (Wiedeń 1913). W 1926 r. ukazuje się dzieło: „Die Sprachfamilien und Sprachenkreise der Erde" z atlasem językowym, przedstawiające dzieje badań historycznoporównawczych nad wszystkimi rodzinami językowymi świata. Autor stwierdza, że budowa języka zmienia się zależnie od rozwoju kultury społeczeństwa. które posługuje się tym językiem. Podkreśla również wpływ, jaki wywierają zmiany kultury materialnej i społecznej na przeobrażenia lingwistycżne, zajmując przez takie nastawienie stanowisko ewolucyjne.

W pracach lingwistycznych Ks. Schmidt posługiwał się w dużej mierze materiałami zebranymi przez misjonarzy, kłórzy w długoletnim współżyciu z tubylcami na ogół gruntowniej poznali ich język, zwyczaje, wierzenia, kulturę materialną i duchowa, niż podróżujący badacze, którzy tylko przejściowo i nieraz pobieżnie zapoznali się z tubylcami. Sprawozdania misjonarzy 
wprawdzie zawsze ceniono, lecz radko wykorzystano je należycie. Zaś ścisły związek, jaki łączy język z kultura, doprowadził powoli Ks. Schmidta do badania liultury a przede wszystkim religii ludów pierwotnych. Dla lepszego wykiorzystania przez ctnologie materiałów etnograficznych, zebranych przez misjonarzy, Ks. Schmidt powoluje do życia w 1906 r. czasopismo "Anthropos" (Revue internationale dethnologic ct de linguistique), w którym uczeni i misjonarze publikuja swoje prace i badania naukowe z dziedziny lingwistyki, etnologii, prehistorii, religiologii w 8 jęylsach a mianowicie $w$ angiclskim, francuskim, hispańskim, holenderskim, polskim, portugalskim, niemieckim i wloskim. Organ ten liczy obecnie 47 tomów, z których każdy obejmuje ponad 1000 stron, oraz dwie serie dzieł naukowych, mianowicie serię ctnologiczną i lingwistyczną, z których każda liczy także kilkanaśoxe tomów.

Dla redagowania tegoż czasopisma Ks. Sehmidt założy w r. 1906 w Wicdniu „Instytut Anthroposu," do którego należy około 30 wspólpracowników różnych narodowości, między innymi i jeden Polak. Nalcżą oni do Zsromadzenia Ks. Ks. Werbistow, których, naczelne kierownictwo przeznaczylo do badań wyłącznie etnologicznych. Oprócz redakcji "Anthroposu" członkowie Instytutu pracuja jako badacze terenowi wśód ludów tubylezych. W ramach tegoż Instytutu nickiórzy jego czlonkowic przeprowadzili kilka ekspedycji do najstarszych ludów. I tak Ks. Koppers wybrał sie do szczepów Ziemi Ognistej i do Bhil w Indiach, Ks. Szebesta zrobił cztery ekspedycje do Pygmejów afrykańskich oraz. Buszmenów i Hotentotów. Ks. Hoeltker do szezepów papuaskich na Nowej Gwinei, Ks. Schumacher zbada? gruntownie Pygmojów szczcpu Batwa w Puandzie, zaś Ks. Vanoverbcrg Negrytów na Filipinach a dr Lcbzelter Buszmenów i Hotentotów. Obecnie Instytut Anthropos z siedziba w Froideville (Szwajcaria) posiada dwic filic, mianowicie w Pombaju i Nagoi. Kilku jego czlonków jest profesorami na uniwersytetach w Wjecniu, Bazylei, Bombaju, Fryburgu, Pckinie, Nagoi, Manili oraz w kilku seminariach duchownych.

Obok wykiadów jako profesor etnologii w Wiedniu i prac organizacyjnych w zwiąrku z czasopismem i instytutem, Anthropos", Ks. Schmidt uwazał za swe zadanie życiowe badania naukowe nad ludami picrwotnymi. I lak w r. 1910 publikuje monografię .,Die Stellung dor Pygmäenvölker in der Entwicklungsgeschichte des Menschen". W której wykazuje fakt niezbity stosunkowo wysokiej moralności i religii u szczepów pygmejskich, należacych do najstarszych przedstawicieli ludzkości. Autor prowadzi dalsze badania $w$ tym samym kierunku, lecz na szerszej podstawie, które publikuje od $1912 \mathrm{r}$. W monumentalnym dziele ..Der Ursprung der Gottesidee". Jest to prawaziwa „Summa gcntilium" w 10 tomach, liczaca ponad 8000 stronic, a manuskrypty 3 dalszych tomów sa juz gotowe do druku. Trudno podac w kilku slowach wynik tak rozlcgłych i gruntownych badań, obcimujacych religię i moralnoś najstarszych ludów, tzw. prakultury i kultur zasadniczych tzn. kregu kulturowego patriarchalno-pasterskiego, matriarchalnego i totemistycznego. Jedno jest pewne z wyników dotychezasowych badań, że stosunkowo wysoka moralność craz monotcizm ludów pierwotnych nie sa produktem rozwoju, lecz spuścizną ludów.

Również socjologia ludów pierwotnych została wciąniẹta w szczegóowe badania Ks. Śchmidta. W 1924 r. ukazuje sie praca: ,Völker und Kulturen“, gdzie Ks. Schmidt na 370 stronicach podaje zwięły przeglad socjologii najstarszych, pierwołnych ludów. Od 1937 do 1942 r. publikuje trzytomowe dzieło 
„,Das Eigentum auf den ältesten Stufen der Menschheit“. Również zagadnieniu rasy i narodowości poświęcił specjalną pracę „Volk und Rasse“ w trzech tomach.

Czytelników „Ruchu Biblijnego i Liturgicznego" interesować będzie działalność Ks. Schmidta w tych również dziedzinach. Otóż w początkach pierwszej wojny światowej właśnie Ks. Schmidt zainicjował w St. Gabriel pod Wiedniem ruch liturgiczny, który później przejął Ks. Pius Parsch i doprowadził do rozkwitu w krajach niemieckich. Również po wojnie Ks. Schmidt publikuje rozprawe: ,Der strophische Aufbau des Gesamttextes der vier Evangelien, oraz „Das Leben Jesu“ w 2 tomach (Wiedeń 1947). Oprócz tego stworzył kilka kompozycji do Lamentationes, Veni Creator, Salve Regina, Miserere i ułożył kilkanaście pieśni kościelnych.

Od 1912 aż do 1938 r. Ks. Schmidt jest profesorem etnologii w uniwersytecie wiedeńskim, tam też stwarza tzw. Szkołę Wiedeńską kulturalno-historyczną etnologii, liczącą obecnie bodaj najwięcej zwolenników wśród etnologów. W 1937 r. wydaje drukiem podręcznik etnologii „Handbuch der Methode der kulturhistorischen Ethnologie“, oraz „Handbuch der vergleichenden Religionsgeschichte" (w r. 1930), które zostały przetłumaczone na język angielski, hiszpański, japoński i włoski.

Badania Ks. Schmidta spotkały się z wielkim uznaniem. W r. 1912, jak już wyżej wspomniano, zostaje powołany na profesora etnologii do Wiednia, gdzie pracuje aż do 1938; w tym roku przenosi się do Szwajcarii, gdzie obejmuje profesurę etnologii we Fryburgu. W r. 1923 Pius XI powierza mu przygotowanie wystawy misyjnej w Watykanie, którą zamieniono później na Pontificio Museo Missionario-Etnologico w Lateranie. W uznaniu zasług położonych na polu nauki i około organizacji tegoż muzeum, Pius XI mianuje go w r. 1927 pierwszym dożywotnim dyrektorem muzeum, a nieco później członkiem Pontificiae Academiae Scientiarum. Również inne instytucje naukowe uznały jego zasługi w dziedzinie wiedzy. Świadczy o tym chociażby fakt nadania mu 6 doktoratów honoris causa uniwersytetów w Bonn, Budapeszcie, Lowanium, Mediolanie, Salzburgu i Wiedniu, oraz nadanie mu członkostwa 21 Akademii Nauk i instytucji naukowych oraz laureatu Académie Française.

Ks. Schmidt w czasie pierwszej wojny światowej pracował jako duszpasterz w armii austriackiej na terenie Polski, przyswoił sobie również język polski do tego stopnia, że udzielał nauki gramatyki języka polskiego seminarzystom w St. Gabriel pod Wiedniem. Jeszcze dotychczas łączy go przyjaźń z niektórymi uczonymi polskimi. Mimo podeszłego wicku niezmordowanie pracuje. Obecnie przygotowuje drugie wydanie, ,Voelker und Kulturen“" i dalsze tomy „Ursprung der Gottesidee“. Dotychczas co do zdrowia czuje siẹ wyśmienicie. To też, kiedy z okazji 80 lecia pewien uczony francuski życzył mu dożycia 90-lecia, Ks. Schmidt z uśmiechem odpowiedział: „Ne fixons pas de termes aux grâces ni aux liberalités de Dicu“.

Gdy już artykuł był złożonyy, nadeszła wiadomość, że J. E. ks. Sch mi d t zmarł dnia 10 lutego w Froideville w Szwajcarii. Zwłoki jego przewieziono do Głównego Domu Ks. Ks. Werbistów, do St. Gabriel w Mödling pod Wịedniem. 